\title{
Stereospecific Opiate-binding Sites Occur in Coated Vesicles ${ }^{1}$
}

\author{
DONALD B. BENNETT,* JAMES W. SPAIN,* MICHAEL B. LASKOWSKI,‡ BRYAN L. ROTH, ${ }^{\star 2}$ AND \\ CARMINE J. COSCIA*,3
}

* E. A. Doisy Department of Biochemistry and $\ddagger$ Department of Physiology, Saint Louis University School of Medicine,

St. Louis, Missouri 63104

\begin{abstract}
We prepared clathrin-coated vesicles from bovine forebrain utilizing sucrose or deuterium oxide-Ficoll density gradient centrifugation followed by permeation chromatography. Homogeneity was monitored by electron microscopy (EM) and sodium dodecyl sulfate-polyacrylamide gel electrophoresis (SDS-PAGE). EM revealed that the predominant (up to $98 \%$ of the total) organelles were coated vesicles and empty hexagonal baskets. Diameters of the coated vesicles ranged from 37 to $120 \mathrm{~nm}$ with a mean of $65.2 \pm 2.2$. Upon SDSPAGE of the coated vesicle fraction, the most prominent band appeared at $\mathbf{1 8 0 , 0 0 0}$ daltons. There were also three additional bands at $100,000,50,000$ and 35,000 daltons, giving the overall pattern characteristic of coated vesicles. Both $0.5 \mathrm{~nm}$ tritiated naltrexone and etorphine displayed specific binding to coated vesicles. Naltrexone binding in coated vesicles from gradient fractions was increased 2.5 -fold over the original $100,000 \times g$ pellet. An additional 4-fold enrichment in specific binding was observed after permeation chromatography which was concomitant with an increase in the volume density of coated vesicles in electron micrographs. Naltrexone binding was stereospecific and etorphine binding was inhibited by $100 \mathrm{~mm} \mathrm{NaCl}(40 \%)$. Both naltrexone and etorphine binding were inhibited by $50 \mu \mathrm{m}$ guanyl-5' $-\mathrm{yl}$ imidodiphosphate (40 to $50 \%$ ). In summary, purified bovine brain-coated vesicles contained high affinity stereospecific opiate alkaloid-binding sites with characteristic opioid binding properties.
\end{abstract}

Coated pits (Roth and Porter, 1964) have been implicated in endocytotic (Pastan and Willingham, 1981; Pearse and Bretscher, 1981) and exocytotic (Friend and Farquhar, 1967; Rothman and Fine, 1980; Rothman et al., 1980) protein transfer in eukaryotic cells. Recoptor-mediated internalization of peptide hormones, lysosomal enzymes, growth factors, and a variety of other proteins via coated pits has been documented by morphological and biochemical evidence (Anderson et al., 1976; Gorden et al., 1978; Maxfield et al.,

Received January 15, 1985; Revised May 6, 1985;

Accepted May 6, 1985

${ }^{1}$ This work was supported by National Science Foundation Grant BNS 8114947. We thank Dr. Suzanne Pfeffer for many helpful discussions and for making available preparative protocols before their publication. We also thank Dr. James Rothman for his suggestions.

${ }^{2}$ Present address: Naval Medical Research Institute, Surgical Research Branch, Bethesda, MD 20814

${ }^{3}$ To whom correspondence should be addressed, at Department of Biochemistry, St. Louis University School of Medicine, 1402 South Grand Boulevard, St. Louis, MO 63104
1978, 1979; Goldstein et al., 1979; Helenius el al., 1980; Mello et al., 1980; Rothman et al., 1980; Wall et al., 1980; Willingham et al., 1981; Campbell et al., 1983; Pilch et al., 1983). Direct observation of this transport process by light and electron microscopy has served as the principal morphological method (Pastan and Willingham, 1981). A biochemical approach (Mello et al., 1980; Pilch et al., 1983) has entailed the demonstration of specific binding sites in coated vesicle preparations that may be derived from coated pits (Pearse, 1975,1978 ) or that may be internal coated vesicles seen in electron micrographs (Friend and Farquhar, 1967; Rothman and Fine, 1980; Rothman et al., 1980; Willingham and Pastan, 1982).

By careful subcellular localization of rat and bovine brain opiate receptors, we have discovered a population of binding sites in smooth microsomes (Roth et al., 1981, 1982). These microsomal sites are candidates for internalized receptors or intracellular precursors of the opiatc rcceptor. Recently, independent reports have appeared on the opioid peptide-induced down-regulation of opiate receptors with concomitant internalization of peptide in cultured aggregated fetal brain cells (Simantov et al., 1982) and neuroblastoma cells (Chang et al., 1982; Gwynn and Costa, 1982; Law et al., 1982, 1981; Blanchard et al., 1983). Evidence for similar brain opiate receptor desensitization in vivo has been inconsistent at best (Pert et al., 1973; Hitzemann et al., 1974; Klee and Streaty, 1974; Höllt et al., 1975). Nevertheless, the turnover of opiate receptors has been demonstrated in vivo (Young et al., 1980).

In light of these observations, it is possible that opiate receptors either could be internalized via the coated pit-endosome pathway or could undergo exocytosis in this manner. We predicted, therefore, that opiate receptors should occur in coated vesicles. In this paper we present evidence for the presence of stereospecific opiate receptors in clathrin-coated vesicle preparations from bovine brain.

\section{Materials and Methods}

Preparation of clathrin-coated vesicles. Coated vesicles from bovine forebrain (obtained and processed immediately after slaughter) were initially prepared by the Blitz et al. (1977) modification of the Pearse (1975) method The procedure entailed $20,000 \times g$ and $100,000 \times g$ differential centrifugations followed by three successive sucrose gradient centrifugations. Routinely, $300 \mathrm{gm}$ of brain tissue afforded $4 \mathrm{mg}$ of protein. Subsequently, a different protocol developed by Pfeffer and Kelly (1985) was adopted. The major modifications of this method included the use of successive linear $\mathrm{D}_{2} \mathrm{O}$-Ficoll gradients and a final step in which the coated vesicles were sized on a $1.5 \times 39 \mathrm{~cm}$ controlled pore (mean pore diameter, $205 \mathrm{~nm}$ ) glass bead column to remove residual contaminants which were generally larger in size than the desired vesicles (Pfeffer and Kelly, 1981). The elution buffer contained $0.2 \mathrm{M}$ sucrose, $0.3 \mathrm{M} \mathrm{NaCl}, 10 \mathrm{~mm}$ HEPES, and $10 \mathrm{~mm}$ EGTA, pH 7.0. Yields were lower than those of the initial method, but nearly homogeneous coated vesicles were obtained.

Dissociation of clathrin coats. Highly purified clathrin-coated vesicles (fraction II) were collected from the glass bead column and centrifuged at $100,000 \times g$ for $1 \mathrm{hr}$. One hall of the pellet was resuspended in $5 \mathrm{ml}$ of 0.5 
M Tris. $\mathrm{HCl}$ buffer, $\mathrm{pH} 7.4$, to promote dissociation of their clathrin coats (Keen et al., 1979). The other half was added to $5 \mathrm{ml}$ of homogenization buffer (10 mM HEPES, $150 \mathrm{~mm} \mathrm{NaCl}, 1 \mathrm{~mm}$ EGTA, and $0.1 \mathrm{~mm} \mathrm{MgCl}$, $\mathrm{pH}$ 7.4) and served as a control. Both mixtures were incubated for $15 \mathrm{~min}$ at $25^{\circ} \mathrm{C}$ and were again centrifuged at $100,000 \times g$ for $1 \mathrm{hr}$. Each of the pellets was resuspended in the column elution buffer and subjected to permeation chromatography once more.

SDS-PAGE. Coated vesicle preparations were solubilized in SDS and run on $8 \%$ polyacrylamide slab gels $(15 \mathrm{~cm})$ according to the procedure of Laemmli (1970). Coomassie blue-stained proteins were quantitated with an LKB 2202 Ultroscan Laser Densitometer set at $640 \mathrm{~nm}$.

Binding assays. Routinely, $0.5 \mathrm{~nm}\left[15,16-{ }^{3} \mathrm{H}\right]$ naltrexone $(26.7 \mathrm{Ci} / \mathrm{mmol})$ or $\left[15,16^{3} \mathrm{H}\right]$ etorphine $(33 \mathrm{Ci} / \mathrm{mmol}$ ) was incubated with 0.2 to $0.5 \mathrm{mg}$ of protein/ assay tube at $25^{\circ} \mathrm{C}$ for $40 \mathrm{~min}$. Binding assays using glass fiber filters were performed as previously described (Roth et al., 1981). Nonspecific binding was determined with $1 \mu \mathrm{M}$ levallorphan.

Electron microscopy. Samples of column and gradient fractions were resuspended in a fixative solution containing $1 \%$ paraformaldehyde and $1 \%$ glutaraldehyde in $0.1 \mathrm{M}$ sodium cacodylate, $\mathrm{pH} 7.4$, and placed in the cold for $1 \mathrm{hr}$. The fixed material was rinsed in sodium cacodylate, post-fixed in $1 \% \mathrm{OsO}_{4}$ for $1 \mathrm{hr}$, and dehydrated in a series of graded ethanols and propylene oxide. Final embedding was carried out in Epox-Araldite (Fullam). Thin sections were cut with a diamond knife on an LKB III Ultramicrotome and, after staining with uranyl acetate and lead citratc, viewed on a Hitachi HU-11E electron microscope.

Assessment of the homogeneity of fractions was based upon an area dernsity anlalysis of electron micrographs (Weibel and Knight, 1964). Five random photographs were taken of sections of each fraction. Electron micrographs were printed on $8 \times 10$ inch sheets at $\times 100,000$ final magnification. A $15-\mathrm{cm}$ circle with 30 random points was placed over each micrograph, and structures underlying the points were noted and tabulated. The percentage of the fraction area occupied by each organelle was calculated and served as the basis for estimating homogeneity of fractions enriched in coated vesicles.

\section{Results}

Preparation and characterization of clathrin-coated vesicles. Homogeneity of coated vesicles, prepared by the Blitz et al. (1977) modification of the original Pearse (1975) method, was monitored by electron microscopy (EM) and SDS-PAGE. EM revealed that the predominant organelles in this preparation were coated vesicles and hexagonal baskets. Upon SDS-PAGE of the coated vesicle fraction, the most prominent band appeared at 180,000 daltons. There were also three less heavily stained bands giving an overall pattern that is characteristic of bovine brain coated vesicles (Blitz et al., 1977; Pearse, 1978; Keen et al., 1979). At least two of the bands have been identified as clathrin heavy and light chains (at 180,000, and 35,000 daltons) (Pearse, 1975), whereas two others appear to be constitutive to coated vesicles $(100,000$ and 55,000 daltons) (Pearse, 1978). These four proteins have been estimated to account for $90 \%$ of the total protein in purified coated vesicles. A scan of three different gels with a laser densitometer revealed that the four bands constitute at least $72 \%$ of the total Coomassie blue-stained material in our preparation. Due to differential staining of protein, this value represents an approximation, but it must be taken into consideration when comparing specific binding activity of coated vesicles with that of other membrane preparations.

Detection of opiate-binding sites. Freshly prepared coated vesicles were immediately used in binding assays with tritiated naltrexone or etorphine (Table I). A 2.5-fold increase in specific naltrexone binding in coated vesicles over the original $100,000 \times g$ sediment was realized. This indicates a specific enrichment of opiate receptors in coated vesicle preparations, even without taking into consideration the predominance of clathrin in these fractions. The coated vesicle receptors recovered represent approximately $5 \%$ of the microsomal subpopulation.

To determine whether authentic opiate receptors were present in coated vesicles, we assessed their stereospecificity and sensitivity to guanine nucleotides and sodium (Simon et al., 1973; Blume, 1978; Childers and Snyder, 1980). Naltrexone binding was stereospecific as shown by the absence of inhibition by $1 \mu \mathrm{M}$ dextroallorphan, the pharmacologically inactive enantiomer of levallorphan that displays low affinity for opioid receptors (Fig. 1). Sensitivity to the guanine nucleotide analogue, $50 \mu \mathrm{M}$ guanyl-5' -yl imidodiphosphate, for both agonist and antagonist binding was also noted, but only the inhibition of etorphine binding was statistically significant. Etorphine binding was also inhibited by $100 \mathrm{~mm} \mathrm{NaCl}$. This inhibition is another criterion of both synaptic plasma membrane (Simon et al., 1973) and microsomal (Roth et al., 1981) opiate receptors. Finally, evidence for saturability and high affinity binding was also obtained. In saturation binding experiments with coated vesicles (fraction II) eluted from the glass bead chromatography column (see below), an apparent $K_{\mathrm{d}}$ of $0.2 \mathrm{~nm}$ for $\left[{ }^{3} \mathrm{H}\right]$ etorphine was estimated (data not shown).

Nonspecific binding in most assays, as determined in the prescnce of $1 \mu \mathrm{M}$ levallorphan, was relatively high (etorphine: $42 \pm 3 \%$, $N=8$; naltrexone: $55 \pm 7 \%, N=5$ ). This could be due either to the relatively low protein concentrations used $(0.3$ to $0.5 \mathrm{mg} / \mathrm{ml})$ and/or to the nature of bovine brain microsomal membranes. Two observations support this interpretation. First, nonspecific binding of naltrexone to crude bovine brain microsomes $(42 \%, N=3)$ and of naloxone to purified (Roth et al., 1982) bovine brain microsomes $(35 \%, N=4)$ (data not shown) were also above normal. Second, nonspecific binding of naltrexone and etorphine was reduced in experiments where protein concentrations were increased 60 to $100 \%$.

Over the range of 0.2 to $0.4 \mathrm{mg}$ of protein $/ \mathrm{ml}$, a linear relationship between etorphine binding to coated vesicle preparations (femtomoles) and protein concentration was observed (correlation coefficient $=0.97$, data not shown). In studies with other membrane fractions and the same ligand concentration, the linear relationship between specific binding and protein concentration did not break down until higher protein levels were used. During the last sucrose density gradient centrifugation, a protein-rich fraction that was slightly less dense than coated vesicle fractions was resolved. Inspection by EM revealed that coated vesicles constituted less than $50 \%$ of this light fraction. Its specific naltrexone binding was less than $50 \%$ of the coated vesicle fraction as well. In contrast, a fraction judged to be $98 \%$ homogeneous by EM exhibited a specific naltrexone $(0.5$ $\mathrm{nm}$ ) binding of $22 \mathrm{fmol} / \mathrm{mg}$ of protein. Accordingly, in these microsomal subfractions the number of opiate-binding sites could be correlated with the purity of coated vesicle preparations.

Preparation of coated vesicles by $D_{2} \mathrm{O}$-Ficoll gradient centrifugalion and permeation chromatography. In subsequent experiments

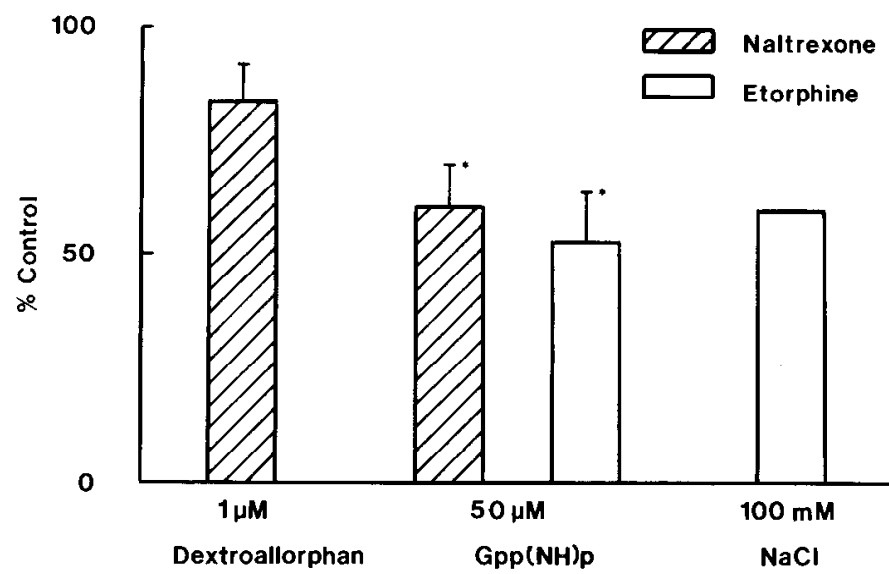

Figure 1. Stereospecificity, $\mathrm{Na}^{+}$ion, and guanine nucleotide sensitivity of oplate binding to bovine torebrain coated vesicles. Purified coated vesicles were assayed as described under "Materials and Methods." Values represent the average of the three separate experiments performed in duplicate except for the study of the $\mathrm{Na}^{+}$shift which was conducted twice. In these experiments 0.3 to $0.4 \mathrm{~nm}\left[{ }^{3} \mathrm{H}\right]$ etorphine was used in binding assays. Mean specific binding of controls was $11 \mathrm{fmol} / \mathrm{mg}$ of protein for naltrexone and $10 \mathrm{fmol} /$ $\mathrm{mg}$ of protein for etorphine. The guanyl- $5^{\prime}-\mathrm{yl}$ imidodiphosphate inhibition of etorphine was statistically significant $\left({ }^{*}, p<0.01\right)$. 
another approach was taken to enrich our preparations in coated vesicles. It had been noted that non-iso-osmotic concentrations of sucrose can cause partial destruction of coated vesicles with some attendant loss of their contents (Nandi et al., 1982; Pearse, 1982). $\mathrm{D}_{2} \mathrm{O}$-Ficoll gradients have been substituted in several different preparative protocols to reduce organelle disruption. In addition, Pfeffer and Kelly $(1981,1985)$ have introduced a final step of controlled pore glass bead permeation chromatography that afforded coated vesicles with fewer membrane protein contaminants. Exogenous radiolabeled synaptic vesicle membranes, that were added to brain tissue before homogenization, were resolved from coated vesicles by permeation chromatography. These and other contaminating organelles were excluded from the glass beads and elute first from the column. Although synaptic vesicle components would not be expected to contain opioid receptors, these procedures clearly provide coated vesicles of much higher purity.

We therefore adopted these innovations to purify our coated vesicles further. After subjecting the microsomal pellet from bovine forebrain to three $\mathrm{D}_{2} \mathrm{O}$-Ficoll continuous gradient centrifugations as described by Pfeffer and Kelly (1985), the partially purified (50 to $80 \%$ ) coated vesicles were loaded onto a controlled pore glass bead column (Fig. 2). As seen in the electron micrographs in Figure 3 , this step eliminated large vesicular contaminants and afforded more homogeneous coated vesicle preparations. Fraction II from the column contained the highest enrichment of coated vesicles as determined by volume density analyses, the highest clathrin concentrations by SDS-PAGE (Fig. 4), and the highest 280-nir absorbance to protein ratio (Fig. 2), and specific binding to opiate receptors showed a 4-fold enrichment over the membranes loaded onto the column (Table I).

Fraction I contained a heterogeneous population of large smooth vesicles and few coated vesicles as judged by EM and SDS-PAGE. It also displayed a higher specific binding that may be due to membrane contaminants. Conversely, the possibility existed that

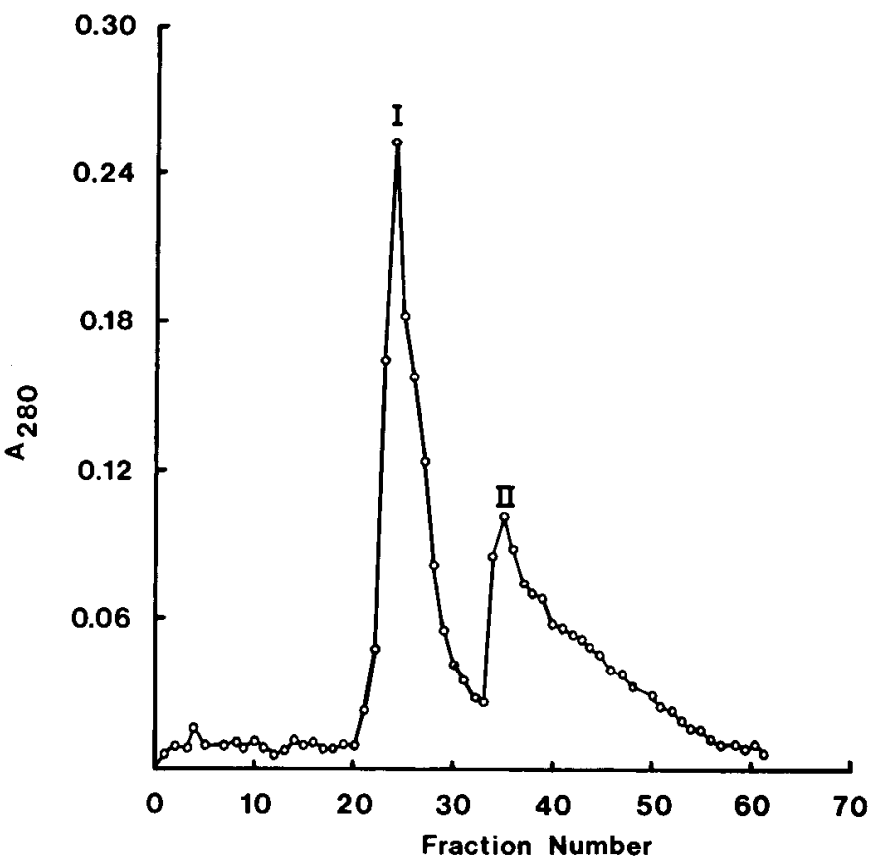

Figure 2. Elution profile of a coated vesicle preparation from a controlled pore glass bead column. Coated vesicles ( $\sim 800 \mu \mathrm{g}$ of protein) purified through three $\mathrm{D}_{2} \mathrm{O}$-Ficoll continuous gradient centrifugations were loaded onto the column. In all chromatographic runs the fractions first to elute from the column contained the lowest amount of coated vesicles by EM (see Fig. 3 ), an inordinately high absorbance at $280 \mathrm{~nm}$ due to light scattering effects of the larger organelles, and the lowest clathrin concentrations as determined by SDS PAGE (sc Fig. 4). The actual protein content of peaks I and II are comparable in this run. some coated vesicles had lost their clathrin and aggregated, giving rise to large smooth vesicles with higher specific binding. To test the latter possibility further, coated vesicles from the peak II fraction were treated either with $0.5 \mathrm{M}$ Tris buffer, $\mathrm{pH} 7.4$, to remove their clathrin coats (Keen et al., 1979) or homogenization buffer to serve as a control (Table II). After the incubation, both treated and control vesicles were centrifuged and the pellets were chromatographed on the glass bead columns once again. The Tris-treated sample displayed a peak ! fraction that had $157 \%$ more protein than the control void volume had, whereas peak II contained only $31 \%$ of that collected in the control peak II fraction. Such a distribution of protein between fractions I and II could occur if a proportion of the coated vesicles were stripped of their clathrin coats, and underwent aggregation. During permeation chromatography, some aggregated vesicles would elute in the void volume. This would explain increased specific binding in fractions I and II (Table I).

The above results suggested that, if clathrin dissociation occurs, aggregation of the uncoated vesicles and elution in fraction I could ensue. Examination of recoveries of the control fraction II coated vesicles (Table II) supported the notion that clathrin dissociation actually did occur during chromatography. Thus, upon rechromatography, the amount of control fraction II recovered was only $32 \%$ of the original loaded onto the column, and a new fraction I had appeared. Furthermore, estimations of protein from the supernatant fractions obtained after centrifugation of the incubation mixture revealed that Tris treatment caused greater losses of protein due to subsequent centrifugation. This may be due to an inability to sediment clathrin triskelion completely at 100,000 $\times$ g. In addition, since triskelion eluted from the column more slowly than does peak II and were not recovered, lower yields were observed with the Tris-treated fraction. The SDS-PAGE results (Fig. 4) also support this interpretalion. Fraction I was devoid of clathrin $(180,000$ daltons) and some coated vesicle-associated proteins (100,000 and 35,000 daltons) that were predominant in fraction II. Nevertheless, there were protein bands (e.g., $\sim 50,000$ daltons) common to both fractions $I$ and II.

The diameters of coated vesicles isolated by $\mathrm{D}_{2} \mathrm{O}$-Ficoll gradient centrifugation and permeation chromatography in this study ranged from 37 to $120 \mathrm{~nm}$ with a mean of $65.2 \pm 2.2$. Large coated vesicles $(>100 \mathrm{~nm})$ represented $<3 \%$ of the total population. Coated vesicle diameters displayed a Gaussian distribution indicative of a single population. The dimensions correspond to those reported for guinea pig brain (50 to $100 \mathrm{~nm}$ ) by Kanaseki and Kadota (1969), for porcine brain (60 to $105 \mathrm{~nm}$ ) by Woods et al. (1978), and for bovine brain (50 to $90 \mathrm{~nm}$ ) by Steven et al. (1983).

\section{Discussion}

In this study bovine brain coated vesicle preparations, judged to be highly purified by EM and SDS-gel electrophoresis, were demonstrated to contained stereospecific, high affinity, opiate alkaloidbinding sites. Sensitivity of agonist and antagonist binding to a guanine nucleotide analogue and inhibition of agonist binding by $\mathrm{Na}^{+}$were alsu observed. The extent of this inhibition was consistent with values previously reported for rat brain membranes (Simon et al., 1973; Blume, 1978; Childers and Snyder, 1980). This specific binding as well as its direct correlation with the proportion of coated vesicles in various fractions (as determined by simultaneous binding assays, SDS-gel electrophoresis, and electron microscopy) lends to obviate possible fortuitous contamination of these preparations with small amounts of opiate receptor-rich membranes. This is also supported by the fact that, in using the supernatant of a $20,000 \times$ $g$ centrifugation as starting material for coated vesicle preparations, the bulk of the synaptic plasma membrane fraction and therefore approximately $70 \%$ of the opiate receptors were eliminated. Any residual plasma membranes should be readily removed by the combination of successive linear $\mathrm{D}_{2} \mathrm{O}$-Ficoll gradients and permeation column chromatography (Pfeffer and Kelly, 1981).

In addition, expcriments shown in Table II provided evidence to suggest that a portion of the smooth membranes eluting in the void 

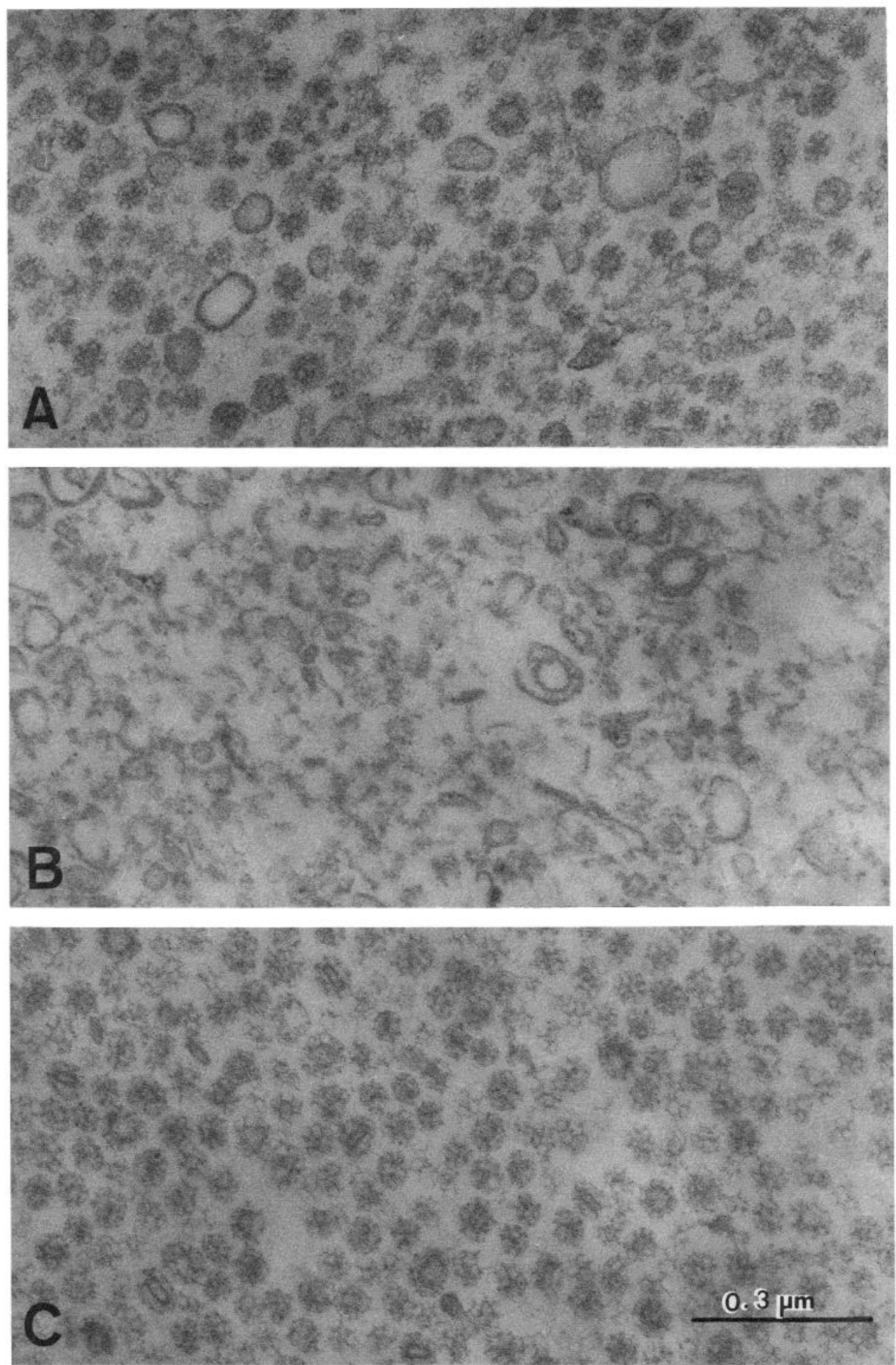

Figure 3. Electron micrographs of a coated vesicle fraction prepared from bovine forebrain. $A$, The preparation taken through successive $\mathrm{D}_{2} \mathrm{O}$-Ficoll density centrifugations (precolumn fraction) containing 60 to $70 \mathrm{~nm}$ of coated and uncoated vesicles, larger, clear vesicles of $100 \mathrm{~nm}$ or more, and uncoated vesicles with a dense center (50 to $100 \mathrm{~nm}$ ). B, The glass bead column-excluded vesicles (fraction I), containing mostly membrane fragments and vesicles with two outer membranes approximately $100 \mathrm{~nm}$ in diameter. Coated vesicles were extremely rare in this fraction. C, Coated vesicle-enriched fraction that was retained on the column (fraction II) containing primarily coated vesicles and baskets with no apparent central vesicle. Occasionally, uncoated vesicles are seen. volume (fraction I) may arise as a result of the dissociation of clathrin coats and the aggregation of the uncoated smooth vesicles. This loss of clathrin is also consistent with the greater specific binding of this fraction. If fraction I arose entirely from uncoated vesicles, it would have displayed specific binding that was 3- to 5-fold greater than that of fraction II. Since this was not the case, it is reasonable to assume that other contaminants were present. Finally, the fact that the control sample in these experiments was recovered in normal yields (Pfeffer and Kelly, 1981) and displayed larger peak ॥ and smaller peak I fractions than the Tris-treated sample supports this line of reasoning as well.
Another characteristic of receptors associated with coated vesicles is a latency due to the fact that the binding site should be on the luminal side of the vesicle (Mello et al., 1980; Pilch et al., 1983). Due to yield considerations, we chose not to test these receptors for latency in the initial studies described here. Instead we selected highly permeable hydrophobic opiate alkaloid ligands to circumvent the problem. In the studies cited above, detergent treatment was used to demonstrate latency, but the opiate receptor is notoriously sensitive to most detergents. In binding studies performed in collaboration with Dr. D. M. Chuang (National Institute of Mental Health), to address this question, we have now detected $\beta$-adrenergic recep- 
$\begin{array}{lllllllllll}A & B & C & D & E & F & G & H & \text { I } & M r \times 10^{3}\end{array}$

Figure 4. SDS-PAGE of bovine forebrain coated vesicles. Glass bead column fractions $(25 \mu \mathrm{g})$ were electrophoresed along with the following protein standards (right lane): myosin $(200,000), \quad \beta$-galactosidase $(116,000)$, phosphorylase b $(97,400)$, bovine albumin $(66,000)$, egg albumin $(45,000)$, and carbonic anhydrase $(29,000)$ The arrow denotes the position of the dye marker. Lanes $A$ to $C$ correspond to fraction I, lane $D$ corresponds to the trough between the two peaks, lanes $E$ to $H$ correspond to fraction II in Figure 2 and Table II, and lane I corresponds to the fraction loaded onto the column. Note the increase in clathrin $(180,000)$ concentration

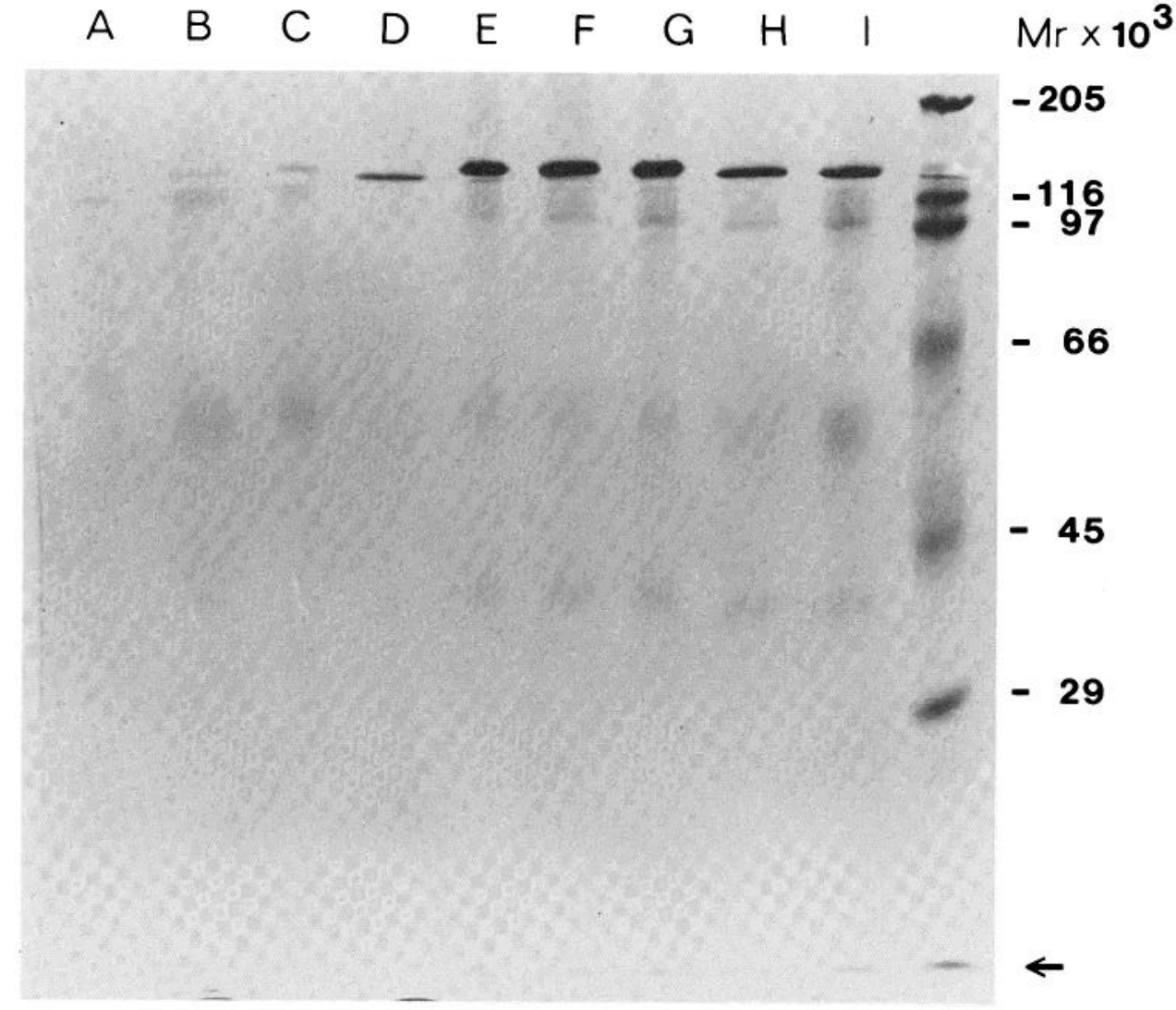

TABLE ।

Opiate binding in coated vesicle preparations from bovine brain "Specific Binding" values represent the average of at least three separate experiments performed in duplicate. The "Permeation Chromatography" data represent the mean from six separate experiments in which coated vesicles were further purified by glass bead chromatography and the fractions were assayed in duplicate. In two of these experiments the coated vesicles used were derived by sucrose density gradient centrifugation (Blitz et al., 1977), whereas for the remainder, the $\mathrm{D}_{2} \mathrm{O}$-Ficoll procedure (Pfeffer and Kelly, 1985) was adopted. Although specific binding varied from experiment to experiment, the average values for the Blitz-Pearse and Pfeffer-Kelly protocols were similar.

\begin{tabular}{|c|c|c|}
\hline \multirow[t]{2}{*}{ Membrane Fraction } & \multicolumn{2}{|c|}{$\begin{array}{l}\text { Specific Binding (fmol/mg of } \\
\text { protein) }\end{array}$} \\
\hline & Naltrexone & Etorphine \\
\hline Forebrain, $100,000 \times g$ pellet & $5.0 \pm 0.85$ & \\
\hline \multirow{2}{*}{$\begin{array}{l}\text { Forebrain, coated vesicles (Blitz- } \\
\text { Pearse) }\end{array}$} & $12.7 \pm 3.1$ & $9.0 \pm 0.79$ \\
\hline & \multicolumn{2}{|c|}{ Permeation Chromatography } \\
\hline $\begin{array}{l}\text { Forebrain-coated vesicles before col- } \\
\text { umn }\end{array}$ & & 15.3 \\
\hline Fraction I & & 69.8 \\
\hline Fraction ॥ & & 52.2 \\
\hline
\end{tabular}

tor latency in coated vesicle preparations. This is not only consistent with previous results but also completely obviates the possibility that the receptors that are present could originate from contaminant synaptic plasma membranes.

In summary, these results implicate coated vesicles in opioid receptor transport in brain. For certain tissues, e.g., liver, vas deferens, and adrenal cortex, inspection by EM has revealed that endocytotic clathrin-coated vesicles derived from the plasma membrane are most likely larger (100 to $160 \mathrm{~nm}$ ) than clathrin-coated vesicles
TABLE ॥

Dissociation of clathrin from purified coated vesicles

\begin{tabular}{llcc}
\hline & & \multicolumn{2}{c}{ Total Units of $\mathrm{A}_{280 \mathrm{~mm}}$} \\
\cline { 3 - 4 } First column run & Fraction 1 & \multicolumn{3}{c}{21.46} \\
& Fraction 2 & & $15.28^{\mathrm{a}}$ \\
\hline & & Tris-treated & Control \\
\cline { 3 - 3 } & & Supernatant & \\
\cline { 3 - 4 } & & 1.04 & 0.54 \\
\hline Second column run & Fraction 1 & 2.02 & 1.28 \\
& Fraction 2 & 0.85 & 2.76 \\
\hline
\end{tabular}

a One-half of the original fraction II was used in each incubation. The recovery of control vesicles $(60 \%)$ was similar to the yields reported originally (Pfeffer and Kelly, 1981).

${ }^{b}$ Supernatant refers to the unsedimented portion of the incubation mixture in which clathrin coats were removed.

found within the Golgi region ( 60 to $80 \mathrm{~nm}$ ) that are reported to be exocytotic (Friend and Farquhar, 1967; Mello et al., 1980; Pfeffer and Kelly, 1981; Willingham and Pastan, 1982). Because of the paucity of large coated vesicles in brain and especially in their subcellular fractions, however, it may not be valid to associate size with an origin in plasma membrane or Golgi apparatus. To determine whether the opiate receptors isolated in the current study are internalized via the coated pit-endosome pathway and/or are undergoing exocytosis in Golgi coated vesicles, a morphological approach will be necessary.

\section{References}

Anderson, R. G. W., J. L. Goldstein, and M. S. Brown (1976) Localization of low density lipoprotein receptors on plasma membrane of normal human fibroblasts and their absence in cells from a familial hypercholesterolemia homozygote. Proc. Natl. Acad. Sci. U. S. A. 73: 2434-2438. 
Blanchard, S. G. K. -J. Chang, and P. Cuatrecasas (1983) Characterization of the association of tritiated enkephalin with neuroblastoma cells under conditions optimal for receptor down regulation. J. Biol. Chem. 258: 10921097

Blitz, A. L., R. E. Fine, and P. A. Toselli (1977) Evidence that coated vesicles isolated from brain are calcium-sequestering organelles resembling sarcoplasmic reticulum J. Cell Biol. 75: 135-147.

Blume, A. J. (1978) Interaction of ligands with the opiate receptors of brain membranes: Regulation by ions and nucleotides. Proc. Natl. Acad. Sci. U. S. A. $75: 1713-1717$.

Campbell, C. H., R. E. Fine, J. Squicciarini, and L. H. Rome (1983) Coated vesicles from rat liver and calf brain contain cryptic mannose 6-phosphate receptors. J. Biol. Chem. 258: 2628-2633.

Chang, K. -J., R. W. Eckel, and S. G. Blanchard (1982) Opioid peptides induce induction of enkephalin receptors in cultured neuroblastoma cells. Nature 296: 446-448.

Childers, S. R., and S. H. Snyder (1980) Differential regulation by guanine nucleotides of opiate agonist and antagonist receptor interactions. J. Neurochem. 34: 583-593.

Friend, D. S., and M. G. Farquhar (1967) Function of coated vesicles during protein absorption in the rat vas deferens. J. Cell Biol. 35: 357-376.

Goldstein, J. L., R. G. W. Anderson, and M. S. Brown (1979) Coated pits, coated vesicles, and receptor-mediated endocytosis. Nature 279: 679684.

Gorden, P., J. -L. Carpentier, S. Cohen, and L. Orci (1978) Epidermal growth factor: Morphological demonstration of binding, internalization, and lysosomal association in human fibroblasts. Proc. Natl. Acad. Sci. U. S. A. 75 $5025-5029$.

Gwynn, G. J., and E. Costa (1982) Opioids regulate cGMP formation in cloned neuroblastoma cells. Proc. Natl. Acad. Sci. U. S. A. 79: 690-694.

Helenius, A., J. Kartenbeck, K. Simons, and E. Fries (1980) On the entry of Semliki forest virus into BHK-21 cells. J. Cell Biol. 84: 404-420.

Hitzemann, R. J., B. A. Hitzemann, and H. H. Loh (1974) Binding of the ${ }^{3} \mathrm{H}$ naloxone in the mouse brain: Effect of ions and tolerance development. Life Sci. 14: 2393-2404.

Hölt, V., J. Dum, J. Bläsig, P. Schubert, and A. Herz (1975) Comparison of in vivo and in vitro parameters of opiate receptor binding in naive and tolerant/dependent rodents. Life Sci. 16: 1823-1828.

Kanaseki, T., and K. Kadota (1969) The "vesicle in a basket": A morphological study of the coated vesicle isolated from the nerve endings of the guinea pig brain, with special reference to the mechanism of membrane movements. J. Cell Biol. 42: 202-220.

Keen, J. H., M. C. Willingham, and I. H. Pastan (1979) Clathrin-coated vesicles: Isolation, dissociation and factor-dependent reassociation of clathrin baskets. Cell 16: 303-312

Klee, W. A., and R. A. Streaty (1974) Narcotic receptor sites in morphinedependent rats. Nature 248: 61-63.

Laemmli, U. K. (1970) Cleavage of structural proteins during the assembly of the head of bacteriophage T4. Nature 2?7: 680-685

Law, P. Y., D. S. Hom, and H. H. Loh (1982) Loss of opiate receptor activity in neuroblastoma $\times$ glioma NG108-15 hybrid cells after chronic opiate treatment. Mol. Pharmacol. 22: 14.

Law, P. -Y., D. S. Hom, and H. H. Loh (1984) Down-regulation of opiate receptor in neuroblastoma $\times$ glioma NG108-15 hybrid cells: Chloroquine promotes accumulation of tritiated erikeph ialin in the lysosomes. J. Biol. Chem. 259: 4096-4104.

Maxfield F. R., J. Schlessinger, Y. Schechter, I. Pastan, and M. C. Willingham (1978) Collection of insulin, EGF and $\alpha_{2}$-macroglobulin in the same patches on the surface of cultured fibroblasts and common internalization. Cell 14 . 805-810.

Maxfield, F. R., M. C. Willingham, P. J. A. Davies, and I. Pastan (1979) Amines inhibit the clustering of $\alpha_{2}$-macroglobulin and EGF on the fibroblast cell surface. Nature 277: 661-663

Mello, R. J., M. S. Brown, J. L. Goldstein, and R. G. W. Anderson (1980) $L D L$ receptors in coated vesicles isolated from bovine adrenal cortex: Binding sites unmasked by detergent treatment. Cell 20: 829-837.

Nandi, P. K., G. Irace, P. P. Van Jaarsveld, R. E. Lippoldt, and H. Edelhoch
(1982) Instability of coated vesicles in concentrated sucrose solutions Proc. Natl. Acad. Sci. U. S. A. 79: 5881-5885.

Pastan, I., and M. C. Willingham (1981) Receptor-mediated endocytosis of hormones in cultured cells. Annu. Rev. Physiol. 43: 239-250.

Pearse, B. M. F. (1975) Coated vesicles from pig brain: Purification and biochemical characterization. J. Mol. Biol. 97: 93-98.

Pearse, B. M. F. (1978) On the structural and functional components of coated vesicles. J. Mol. Biol. 126: 803-812.

Pearse, B. M. F. (1982) Coated vesicles from human placenta carry ferritin, transferrin, and immunoglobulin G. Proc. Natl. Acad. Sci. U. S. A. 79: 451 455

Pearse, B. M. F., and M. S. Bretscher (1981) Membrane recycling by coated vesicles. Annu. Rev. Biochem. 50: 85-101.

Pert, C. B., G. Pasternak, and S. H. Snyder (1973) Opiate agonists and antagonists discriminated by receptor binding in rat brain. Sci. 182: 13591361.

Pfeffer, S. R., and R. B. Kelly (1981) Identification of minor components of coated vesicles by use of permeation chromatography. J. Cell Biol. 91: 385-391

Pfeffer, S. R., and R. B. Kelly (1985) The subpopulation of brain coated vesicles that carries synaptic vesicle proteins contains two unique proteins. Cell 40: 949-957.

Pilch, P. F., M. A. Shia, R. J. J. Benson, and R. E. Fine (1983) Coated vesicles participatc in the rocoptor mediated endocytosis of insulin. J. Cell Biol. 93: 133-138.

Roth, B. L., M. B. Laskowski, and C. J. Coscia (1981) Evidence for distinct subcellular sites of opiate receplors. Demonstration of opiate receptors in smooth microsomal fractions isolated from rat brain. J. Biol. Chem. 256: 10117-10123.

Roth, B. L., M. B. Laskowski, and C. J. Coscia (1982) Microsomal opiate receptors differ from synaptic membrane receptors in proteolytic sensitivity. Brain Res. 250: 101-109.

Roth, T. F., and K. R. Porter (1964) Yolk protein uptake in the oocyte, the mosquito Aedes aegypti L. J. Cell Biol. 20: 313-332.

Rothman, J. F., and R. E. Fine (1980) Coated vesicles transport newly synthesized membrane glycoproteins from endoplasmic reticulum to plasma membrane in two successive stages. Proc. Natl. Acad. Sci. U. S. A. $77: 780-784$

Rothman, J. E., H. Burszytn-Pettegrew, and R. E. Fine (1980) Transport of the membrane glycoprotein of vesicular stomatitis virus to the cell surface in two stages by clathrin-coated vesicles. J. Cell Biol. 86: 162-171.

Simantov, R. D. Baram, R. Levy, and H. Nadler (1982) Enkephalin and $\alpha$ adrenergic receptors: Evidence for both common and differentiable regulatory pathways and down-regulation of the enkaphalin receptor. Life Sci. 31: $1323-1326$.

Simon, E. J., J. M. Hiller, and I. Edelman (1973) Stereospecific binding of the potent narcotic analgesic $\left[{ }^{3} \mathrm{H}\right]$ etorphine to rat brain homogenate. Proc. Natl. Acad. Sci. U. S. A. 70: 1947-1949

Steven. A. C., J. F. Hainfeld, J. S. Wall, and C. J. Steer (1983) Mass distributions of coated vesicles isolated from liver and brain: Analysis by scanning transmission electron microscopy. J. Cell Biol. 97: 1714-1723.

Wall, D. A., G. Wilson, and A. L. Hubbard (1980) The galactose-specific recognition system of mammalian liver: The route of ligand internalization in rat hepatocytes. Cell 21: 79-93.

Weibel, E. R., and B. W. Knight (1964) A morphometric study on the thickness of the pulmonry air-blood barrier. J. Cell Biol. 21: 367-384.

Willingham, M. C. and I. H. Pastan (1982) Transit of epidermal growth factor through coated pits of the Golgi system. J. Cell Biol. 94: 207-212.

Willingham, M. C., I. H. Pastan, G. G. Sahagian, G. W. Jourdian, and E. F. Neufeld (1981) Morphologic study of the internalization of a lysosomal enzyme by the mannose 6-phosphate receptor in cultured Chinese hamster ovary cells. Proc. Natl. Acad. Sci. U. S. A. 78: 6967-6971.

Woods, J. W. M. P. Woodward, and T. F. Roth (1978) Common features of coated vesicles from dissimilar tissues: Composition and structure. J. Cell Sci. 30: 87-97.

Young, W. S., J. K. Wamsley, M. A. Zarlin, and M. J. Kuthan (1980) Opiate receptors undergo axoplasmic flow. Science 210: 76-78. 